\title{
ROOT KNOT DISEASE CAUSED BY MELOIDOGYNE INCOGNITA (KOFOID \&WHITE, 1919) CHITWOOD, 1949 (NEMATODA, MELOIDOGYNIDAE) ON TOMATO GROWN IN SOIL-LESS CROPS IN ITALY
}

\author{
(*) University of Naples Federico II, Department of Agricultural Sciences, 80055 Portici, Naples, Italy. \\ (**) Consiglio per la ricerca in agricoltura e l'analisi dell'economia agraria (CREA-ABP), Research Centre for \\ Agrobiology and Pedology, 50125 Florence, Italy. \\ (***) Indian Agricultural Research Institute, Pusa Campus, New Delhi, India. \\ Corresponding author: giada.derrico@unina.it
}

\begin{abstract}
d'Errico G., Giacometti R., Roversi P.F., Prasad L., Woo S.L. - Root Knot disease caused by Meloidogyne incognita (Kofoid \& White, 1919) Chitwood, 1949 (Nematoda Meloidogynidae) on tomato grown in soil-less crops in Italy.

Infestation of Meloidogyne incognita (Kofoid \&White, 1919) Chitwood, 1949 on tomato grown in a soil-less system is reported from the Nola area, southern Italy. Morphological observations and measurements of females and second stage juveniles of the nematode conformed to those reported in the description of M. incognita. Advantages and disadvantages of soil-less crops on the spread of the nematode are also discussed.
\end{abstract}

KEY WoRDS: Greenhouse, soil-less crop system, tomato, coconut fiber, root-knot nematodes.

\section{INTRODUCTION}

Soil-borne pests and diseases, especially plant pathogenic fungi and phytoparasitic nematodes, are the main problems for horticultural crops grown under field conditions. Their combination enhance the nematode development causing synergistic damages (RAGOzZINO \& D'ERRICO, 2011). Nematode problems have increased following the ban of fumigants having biocidal (methyl bromide) or nematicidal (1,3-Dichloropropene) activities. The main nematode pests are Meloidogyne species that can attack a great number of crops or, in their absence, weeds (D'ERRICO et al., 2014). In greenhouse, soil-less crops are used to avoid these problems (ASADUZZAMAN et al., 2015). There are few reports of root knot nematode diseases in soil-less cultivation systems. Moens \& HENDRICKX (1990) reported the presence of M. incognita (Kofoid \&White, 1919) Chitwood, 1949 on ornamental plants in Belgium. Thereafter, mixed populations of $M$. arenaria (Neal,1889) Chitwood, 1949 and M. incognita were reported on rose in Italy by D'ERRICO \& INGENITO (2003), M. hapla Chitw. on rose grown in rockwool and coconut-peat cultures in Germany (HALLMANN et al., (2004), and M. javanica (Treub, 1885) Chitwood, 1949 on cucumber grown in rock-wool medium in Greece (TzORTZAKAKIs, 2004). Once nematodes have entered into the soil-less crop, they can reproduce and disseminate rapidly thus resulting in devastating effect on the crop in a short time.

Tomato [Solanum lycopersicum (L.) Karten ex Farw] is an economical important greenhouse crop in many regions of the world and there are no reports of root-knot nematode infestation from soil-less culture. The cultivation of tomato in greenhouses in Italy is a common practice during the winter, and plays an important role, involving $7.3 \%$ of the Italian tomato area with a production of $8.6 \%$ (ISTAT, 2014). In Italy, in the soilless technique the use of bags prevails under greenhouse conditions. In October 2014, tomatoes grown in the greenhouse using coconut fiber linear bag containers, combined with an open system irrigation (i.e., once the water is delivered to the plant roots, it is not reused), exhibited stunted growth, chlorotic leaves and large rootgalls. Therefore, this is an additional report on the occurrence of root knot nematodes in soil-less crops.

\section{MATERIALS AND METHODS}

The greenhouse, in which coconut fiber was used as soilless substrate without recycling of water, was located in the Nola area, Naples (southern Italy). Three tomato plants were cultured in each of the polyethylene bag of $105 \mathrm{~cm} \times 30 \mathrm{~cm}$ and of 42 litre capacity. The bags were placed flat on the floor at normal row spacing for tomato. Infected tomato plants (about 3 months old) exhibited galls or knots throughout the root system, typical symptoms caused by root-knot nematodes (Fig. I, 1 and 2). The infected plants were not evenly distributed throughout the greenhouse; they were confined to plants in some of the bags whereas plants in other bags of the greenhouse were healthy (Fig. I, 3).

Samples of substrate and root of tomato cv. Akira, were collected from the bags containing the infected plants and consisted of $10 \mathrm{~cm}^{3}$ of substrate and 5 grams of fresh root. The root system was carefully washed with tap water to remove the adhering substrate. Then forty females were collected from the roots using a dissecting microscope and 

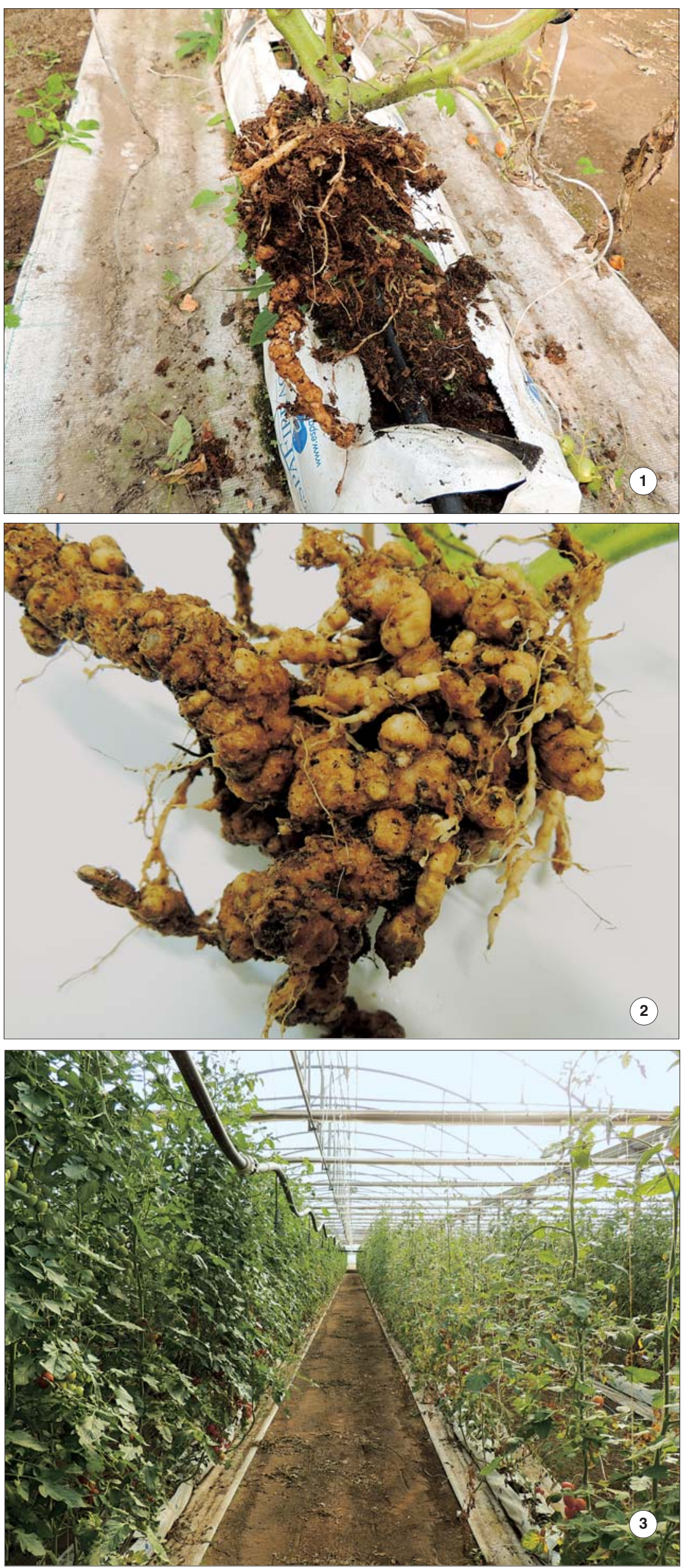

Fig. I - Tomato root exibiting galls of the nematode attack (1); Detail of a root system infested by Meloidogyne incognita (Kofoid \&White, 1919) Chitwood, 1949 (2); Tomato greenhouse soil-less production system utilizing linear bag culture containing coconut fiber substrate (3). 
measured with a micrometer. The perineal patterns of the females were prepared and observed under a Leitz ORTHOPLAN light microscope at up to $1000 \times$ magnification. The identification of the nematode to species level was based on morphological characteristics of females and second-stage juveniles (J2s) (EISENBACK et al., 1981).

The J2s were extracted from the substrate by Cobb's sieving and decanting method combined with a modified Baermann's funnel technique for 10 days at $22 \pm 2^{\circ} \mathrm{C}$, to allow most of the eggs to hatch, and then counted under a microscope in a specially designed chambered counting dish. J2s from roots were extracted by the cottonwool filter method for 48 hours at $22 \pm 2^{\circ} \mathrm{C}$, then counted as previously described. Eggs were collected from infected roots by shaking the chopped clean roots in a $0.5 \%$ solution of sodium hypochlorite for 3 minutes (Hussey \& Barker, 1973). For identification, forty J2s were killed by heating followed by temporary mounting on glass slides and morphological measurements recorded.

\section{RESULTS}

Nematodes were found in all infested samples and population densities ranged from 760 to $1,980 \mathrm{~J} 2 \mathrm{~s}$ per 10 $\mathrm{cm}^{3}$ of substrate, and 1,280 to 4,700 eggs and J2s/5 g in the root samples. Perineal patterns of the females had a high squared dorsal arch with wavy striae and lateral field marked by breaks and forks in the striae. All morphological measurements conformed to those reported in the description of $M$. incognita (Table 1). being conducted to find effective methods for decontaminating the circulating water (HUGO \& MALAN, 2010). Some of the most important sources of nematode infestation originate from infected planting material, soil and potting media, the irrigation water and a lack of sanitary practices. Thus, attention must be paid to avoid the introduction of the nematodes into the system, including movement of personnel and equipments from the field to the greenhouse.

The choice of the planting substrate to be used in the soilless crop system is also very important. Artificial substrates, such as rock wool, ceramic granules, vermiculite, perlite, polystyrol, etc., are preferred and considered safer than natural sources such as rock, clay, sand, pumice, peat, bark, coconut coir, etc. Artificial substrates are supposed to be clean, not having had the "original" contact with contaminants, or possibility of infestation during production. Moreover, these materials are ready for use (natural products need to be pasteurized or sterilized prior to use). However, problems may occur in the greenhouse cultural system if appropriate sanitation practices are not followed (HALlmanN et al., 2005; Noling \& RicH, 2012).

In our study case, because of the limited distribution of infested plant material throughout the greenhouse, it is assumed that the source of nematode infection was not from the substrate, irrigation water, nor from the nursery seedlings, but likely it was caused by the lack of appropriate sanitary practices. There are numerous environmental and ecological advantages to recycling irrigation water for horticultural purposes (SCHNITZLER, 2004) but the use of recycled water for irrigation in greenhouses may increase the dispersal of plant pathogens (STEWART-

Table 1 - Measurement of $\mathrm{J} 2 \mathrm{~s}$ and female structures of nematodes collected from substrate and root samples of tomato soil-less cultures. Data are mean \pm standard deviation of 40 measurements.

\begin{tabular}{lcccc}
\hline \hline \multicolumn{2}{c}{ Measurements $(\mu \mathrm{m})$} \\
\hline \multicolumn{2}{c}{ Juveniles second-stage $(\mathrm{J} 2 \mathrm{~s})$} & $11.2 \pm 0.1$ & & \multicolumn{2}{c}{ Females } \\
\cline { 1 - 1 } \cline { 4 - 5 } Stylet length & $408 \pm 3.1$ & & $\mathrm{~L}$ & $16.3 \pm 0.3$ \\
Mean body length (L) & $25.8 \pm 0.4$ & & Body width & $889.2 \pm 27.9$ \\
L/maximum body width & $6.1 \pm 0.1$ & & \\
L/esophageal length & $9.7 \pm 0.1$ & & \\
L/tail length & $47.2 \pm 0.2$ & & \\
Tail length & $10.4 \pm 0.2$ & & \\
Hyaline tail & & & \\
\end{tabular}

\section{DISCUSSION}

The major advantage of soil-less culture would be the opportunity to start a crop production cycle in a system in the absence of soil-borne pests and diseases. In the past, the management of pathogens and pests in greenhouse was largely based on soil fumigation with methyl bromide (MB), but following the ban of $\mathrm{MB}$, nematode problems have increased. However, it has been observed that the use of soil-less culture system does not guarantee the exclusion of infestations by plant parasitic nematodes (SChNitZler, 2004; CombrinK, 2005; Hallmann et al., 2005). Moreover, the introduction of the pest into the closed irrigation system, may cause severe damage to the cultivation in a short time due to the quick and uniform distribution of the nematode by the contaminated recycled water throughout the greenhouse. Therefore, recycling of greenhouse irrigation water should be avoided. Studies are

WADE, 2011). In the greenhouse many bags did not contain infected plants while when plants were infected they were all the same bags. This indicates that the use of separate planting bags may be useful in limiting the spread of the nematodes, and that the nematode infested plants can be easily isolated, removed and substituted with non infested bags. In order to safeguard seedlings before transplanting, the use of a plastic film under the propagation or nursery trays to isolate the plantings and prevent contact with the ground soil that could result infested with nematodes, is highly recommended.

\section{REFERENCES}

Asaduzzaman M., Saifullah M., Mollick A.S.R., Hossain M.M., Halim G.M.A., Asao T., 2015 Influence of Soilless Culture Substrate on Improvement 
of Yield and Produce Quality of Horticultural Crops. http://dx.doi.org/10.5772/59708.

Butt S.J., Varis S., Ahmad Z., Gurmani A. R., FarooQ A., 2014 - The potential use of soilless and soil based growing media, including grapes residue as an introductory evaluation, for the production of Lactuca sativa L. through bag culture. - Life Sciences Leaflets, 49: 48-60.

Combrink N.J.J., 2005 - Nutrient solutions and greenhouse management. - Stellenbosch : Combrink Family Trust, Matieland: 106-110.

D'ERRICO F.P., INGENITO E., 2003 - Occurrence of the rootknot nematodes Meloidogyne incognita and M. arenaria in soilless cultures of rose. - Nematol. medit., 31: 89-90.

D'ERrico G., CrescenZI A., LANDI S., 2014 - First Report of the Southern Root-Knot Nematode Meloidogyne incognita on the Invasive Weed Araujia sericifera in Italy. - Plant Disease, 98:1593.

Hallmann J., Hänisch D., Braunsmann J., Klenner M., 2005 - Plant-parasitic nematodes in soilless culture system. - Nematology, 7: 1-4.

Hugo J.H., Malan A.P., 2010 - Occurrence and Control of Plant-parasitic Nematodes in Irrigation Water. - A Review. S. Afr. J. Enol. Vitic., 31 (2): 169-180.

HusSEY R.S., BARKER K.R., 1973 - A comparison of methods of collecting inocula of Meloidogyne spp., including a new technique. Plant Disease Report, 57: 1025-1028.
ISTAT, 2014 - Superfici e produzioni delle principali coltivazioni. - http://www.istat.it.

Moens M., Hendrickx G., 1990 - Nematode infection by recirculating nutrient solutions in gullies. Meded. - Fac. Landbouwwet. Rijksuniv. (gent), 55: 739-743.

Noling J.W., Rich J.R. (Eds), 2012 - Florida Greenhouse Vegetable Production Handbook. - Horticultural Sciences, 3: 1-6.

PAPADOPOUlos A.P., 1994 - Growing Greenhouse Seedless Cucumbers in Soil and Soilless Media. - Agriculture and Agri-Food Canada Pub. No. 1902/E, 126 pp.

RAgOzZINo A., D'ERrico G., 2011 - Interactions between nematodes and fungi: a concise review. - Redia, XCIV: 123-125.

SCHNITZLER W.H., 2004 - Pest and disease management of soilless culture. - Acta Hortic. 648: 191-203.

StewART-WAdE S.M., 2011 - Plant pathogens in recycled irrigation water in commercial plant nurseries and greenhouses: their detection and management. Irrigation Science 29: 267-297.

TZORTZAKAKIS E.A., 2004 - Detection of the root-knot nematode, Meloidogyne javanica in cucumber hydroponic culture in Crete, Greece. - Nematol. Medit. 32: 241-242.

Zhibin Z., 1999 - Update development of protected cultivation in Mainland China. - Chronica Horticulturae, 39(2): 11-18. 